\title{
COMMENT
}

\section{THE NEW SHERMAN-CLAYTON-NORRIS-LAGUARDIA ACT}

\author{
Chardes O. Gregory*
}

7 HIS critical discussion is now being advanced not because I dislike the decision in the Hutcheson case, ${ }^{\mathrm{I}}$ but because I dislike Mr. Justice Frankfurter's opinion. Most of the legal profession are reconciled to the decision because I believe they expected it. Indeed, some of us would not have been surprised if the Court had revitalized Section 6 of the Clayton $\mathrm{Act}^{2}$ and declared that Congress had thereby intended to free labor unionists completely from the strictures of the Sherman Act, albeit Congress had (as we all thought) failed to correct the "false impression" of the Supreme Court concerning this section in spite of frequent opportunities since I92I. ${ }^{3}$ Mr. Justice Stone's concurring opinion in the Hutcheson case could almost have been outlined in advance, after a careful reading of what he said in the $A$ pex case. ${ }^{4}$ But who could have seriously supposed that the Court would reach its result by the devious route outlined in Mr. Justice Frankfurter's opinion and acquiesced in by three other associate justices?

\section{I}

The majority opinion displays a boldness of judicial technique seldom to be observed. With admirable deftness, the learned Justice unequivocally removed all of organized labor's organizational and bargaining devices, including inter-union competitive strife, beyond the reach of the Sherman Act. A dictum alone suggests that union combinations with non-union groups to effect control of commodity markets will still be unlawful under the anti-trust laws. ${ }^{5}$ Perhaps only the memory of the older Court's unani-

* Associate Professor of Law, University of Chicago.

I United States v. Hutcheson, 6I S. Ct. 463 (r94r).

2 Concerning the vitality of Section 6 of the Clayton Act, 38 Stat. 73I (x9I4), I5 U.S.C.A. $\S$ I7 (1927), see Gregory, The Sherman Act v. Labor, 8 Univ. Chi. L. Rev. 222, 242 (194I).

3 Duplex Printing Press Co. v. Deering, 254 U.S. 443 (x92r).

4 Apex Hosiery Co. v. Leader, 3 ro U.S. 469 (1940). See Cavers, Labor v. The Sherman Act, 8 Univ. Chi. L. Rev. 246 (I94I). See also Gregory, The Sherman Act v. Labor, 8 Univ. Chi. L. Rev. 222 (194I).

5 "So long as a union acts in its self-interest and does not combine with non-labor groups. ..." 6I S. Ct. 463,466 (I94I), citing United States v. Brims, 272 U.S. 549 (I926). 
mous opinion in the Brims case $^{6}$ kept the majority of the present Court from resurrecting Section 6 of the Clayton Act to obviate even this remaining possibility. Union lawyers, however, can console themselves with the reflection that, after all, this qualification was only a dictum!

The Court's Hutcheson opinion is not easily digested, since it is a departure from the conventional methods of judicial reasoning and is at variance with statutory interpretations which most of the profession had for years assumed to have been settled. It comprises a sort of joint exegesis of what Mr. Justice Frankfurter calls "these three interlacing statutes"that is, the Sherman, the Clayton and the Norris-LaGuardia acts. In the interpretation which he evolves, the learned Justice seems to ignore what may be termed the "intellectual frame of reference" to which lawyers and judges in the past have clung as the only security against sinking into the bewildering chaos of shifting social values in a changing world. Perhaps his departure from these traditional grooves of thinking is salutary. But this is a speculation with which I could expect little agreement. I would suppose, rather, that many believe Mr. Justice Frankfurter to have thrown compass and sextant overboard and to be henceforth steering by dead reckoning, or by his stars. Before final judgment is passed, however, I think he is entitled to a more complete understanding than most people have as yet been willing to give his opinion in the Hutcheson case.

Current notions concerning Mr. Justice Frankfurter's achievement in that case rest chiefly upon the snap judgments formed on February 4, I94I, when the news of the decision appeared in the daily papers. Many readers apparently gained the impression that the Court had construed the Norris-LaGuardia Act, ${ }^{7}$ purely an anti-injunction statute, to have foreclosed recourse as well to actions for damages and criminal proceedings against unions. Naturally all who had a modicum of legal knowledge and who believed that the Court had done this were shocked. But such an interpretation of Mr. Justice Frankfurter's opinion is, I believe, entirely erroneous, although those who are sufficiently unbiased and reflective to understand what his rationale was and how it looks in its proper context may be quite as disturbed as they were from their first impression.

That part of the learned Justice's opinion with which issue is most directly taken reads as follows:

To be sure, Congress [in the Norris-LaGuardia Act] expressed this national policy and determined the bounds of a labor dispute in an act explicitly dealing with the further withdrawal of injunctions in labor controversies. But to argue, as it is urged be-

6 United States v. Brims, 272 U.S. 549 (I926).

${ }_{47}$ Stat. 70 (1932), 29 U.S.C.A. § ror (Supp. 1940). 
fore us, that the Duplex case still governs for purposes of a criminal prosecution is to say that that which on the equity side of the court is allowable conduct may in a criminal proceeding become the road to prison. It would be strange indeed that although neither the Government nor [the employer] could have sought an injunction against the acts here challenged, the elaborate efforts to permit such conduct failed to prevent criminal liability punishable with imprisonment and heavy fines. That is not the way to read the will of Congress, particularly when expressed by a statute [not indicating which one] which, as we have already indicated, is practically and historically one of a series of enactments touching one of the most sensitive national problems. Such legislation must not be read in a spirit of mutilating narrowness. ${ }^{8}$

Issue may be taken with this passage by quoting from previous writings of Mr. Justice Frankfurter, published when he was a professor at the Harvard Law School. Attention may be called to The Labor Injunction, ${ }^{9}$ a learned and effective plea against the use of injunctions to curb the selfhelp methods of organized labor and in favor of the then pending NorrisLaGuardia bill. Answering the contention that the act would withhold from complainants all remedy for the wrongs they might suffer, the authors state: "No such interpretation is possible for the proposed bill, which explicitly applies only to the authority of United States courts 'to issue any restraining order or injunction.' All other remedies in federal courts and all remedies in state courts remain available." ${ }_{\text {Io }}$ In an article a year later entitled "Congressional Power over the Labor Injunction," Professor Frankfurter as part of a thesis urging adoption of the NorrisLaGuardia bill propounded this question: "Is the denial of all adequate judicial remedies in case of an illegal strike a denial of due process of law?" He answered: "This question is not pertinent, for the bill only withdraws the remedy of injunction. Civil action for damages and criminal prosecution remain available instruments. Illegal strikes are not made legal."

Of course, anyone taxing the learned Justice with these statements he made ten years ago invites the rejoinder (recently popularized by Senator Ashurst) that consistency is the refuge of small minds. Nevertheless, it is irritating to realize that Mr. Justice Frankfurter ten years ago was sure that the proposed anti-injunction act was intended to have no effect on the substantive law, but was designed to prevent, in enforcing that law, the abuse which had become a routine incident, i.e., the misused injunc-

${ }^{8} 6$ I S. Ct. 463,467 (194r).

9 Frankfurter and Greene, The Labor Injunction (1930).

ro Ibid., at 220.

Ix Frankfurter and Greene, Congressional Power over the Labor Injunction, $3^{\text {I }} \mathrm{Col}$. L. Rev. 385,408 (I93r). 
tions against labor unionists. He knew in I930 that adoption of the Norris-LaGuardia Act would, for practical purposes, virtually "legalize" conduct against which the only convenient remedy was the injunction; for employers would generally not bother with suits for damages or with initiating criminal proceedings, except under aggravated circumstances, if they could not have the objectionable conduct stopped immediately. This, no doubt, was implicit in the advantage which labor sought in the passage of the act. But it is hard to believe, after reading his decade-old statements quoted above, that the learned Justice at that time harbored the conviction that once the Norris-LaGuardia Act was passed, it would -by implication or otherwise-revitalize Section 20 of the Clayton Act and in effect operate as a legislative legitimation of all specified labor activities under the guise of merely affording a jury trial for their fair prosecution.

The Labor Injunction shows, taken in its entirety, that the authors were most disturbed about the ease and informality with which business men throttled union self-help organizational and bargaining pressures without according the unionists the guarantees of due process inherent in the ordinary civil action for damages with its pleading stage and trial by jury, and in ordinary criminal proceedings with indictment or information and trial by jury. The book reads as if the authors did not have the Sherman Act in mind at all, except insofar as the injunctive sanction was available under it; and from the discussion of the labor sections of the Clayton Act one gets the impression that Congress' attempt to help labor unions, having been smothered by the Supreme Court in the Duplex case, would best be left relegated to the oblivion which the pending bill's adoption would certainly insure.

It is possible, of course, that when the book and article cited above were written, Mr. Justice Frankfurter had in the back of his mind the concluding phrase of Section 20 of the Clayton Act, ${ }^{12}$ and believed that the passage of the Norris-LaGuardia bill without specific repeal of Section 20 would make his assurances perfectly safe but practically meaningless by revitalizing Section 20. For then all of the union conduct in question would be lawful for all purposes anyhow; and discussion of an anti-injunction act denying all other remedies as well would become academic, since Congress by enacting the Norris-LaGuardia bill would already have eliminated these other remedies. But I prefer to believe that Mr. Justice Frankfurter had no such thoughts in his mind a decade ago; and I feel

$x 2$ ".... nor shall any of the acts specified in this paragraph be considered or held to be violations of any law of the United States." 38 Stat. $73^{8}$ (I9I4), I5 U.S.C.A. $\$ 52$ (Ig27). 
absolutely sure that if he had, he would certainly have included them in his writings. Nevertheless, proof of the learned Justice's good faith does not relieve him of the charge of inconsistency, however unimportant this feature may seem in questioning the use of convenient pensées d'escalier on which to raise a structure of Congressional intent convincing few except those already persuaded.

The fact remains, then, that Mr. Justice Frankfurter, having assured the profession in I930 that "all other remedies [besides injunctive relief] in federal courts and all remedies in state courts remain available" if the Norris-LaGuardia bill be adopted, now says that after its adoption certain remedies established by Congress in the Sherman Act (civil suits for triple damages and criminal proceedings), and heretofore thought by the Supreme Court itself to apply to some of the conduct enumerated in Section 20 of the Clayton Act and Section 4 of the Norris-LaGuardia Act when indulged in restraint of commerce, are no longer available because of the passage of the Norris-LaGuardia Act. The wording of the quotation above-the use of the word "other" and the indication that all remedies in state courts remain unaffected-clearly reveals his inconsistency. And his conviction of I930 reflected what was everywhere generally believed when the Norris-LaGuardia bill was pending: that its protagonists meant it to be only a regulation upon the issuance of injunctions by federal courts. That Congress in promulgating the act so intended seems clear; and the fact that it did not go farther and expressly legalize for all purposes the conduct made non-enjoinable as its former incumbents had taken the pains to do with Section 20 of the Clayton Act and as the Wisconsin legislature had already done in its similar anti-injunction act ${ }^{\mathrm{t3}}$ is not the Supreme Court's business, but is the affair of Congress. One is almost inclined to disagree with Judge Otis who so pointedly emphasized that whatever else one might think of Professor Frankfurter, it would certainly be believed that he knew what he meant in what he wrote. ${ }^{14}$

Mr. Justice Frankfurter does not say in his Hutcheson opinion that Congress intended in 1932 to enact any more than an anti-injunction measure. He merely says that, after reading Congress' statement of public policy in Section 2 of the act as well as the remainder of the act-all in light of Section 20 of the Clayton Act, which is still on the books-he believes (and therefore holds) that Congress in this statute intended to overrule the Duplex case and to reinstate what he is convinced Congress intended to be the law of the land in I9r4. Is this reasoning justifiable? Congress in

13 Wis. Stat. (1937) § 103.56.

${ }_{14}$ Dissenting in Donnelly Garment Co. v. ILGWU, 2 I F. Supp. 807, 82 I (Mo. 1937). 
the act itself and the drafters of the bill (probably including Professor Frankfurter" ${ }^{15}$ ) went to great length to spell out a definition of "labor dispute ${ }^{316}$ which would effectively dispel the notion read into Section 20 of the Clayton Act by the Court in the Duplex case that the anti-injunction provisions in such section would apply only in those labor disputes occurring between parties in the so-called "proximate" relationship of employer and employee. After such painstaking efforts to make certain on this matter, it seems significant that neither Congress nor its expert advisers, including Professor Frankfurter, took the trouble to make clear in the new statute that the union self-help conduct outlined in the second paragraph of Section 20 of the Clayton Act and substantially repeated in Section 4 of the Norris-LaGuardia Act was to be made lawful for all purposes or even to repeat the clause of Section 20 of the Clayton Act which reads: ".... nor shall any of the acts specified in this paragraph be considered or held to be violations of any law of the United States." This omission, in light of the very conclusion of Section 20 just quoted, and in light of the similar well-known provision in the Wisconsin "little Norris-LaGuardia act," promulgated nine months before Congress adopted the NorrisLaGuardia Act, ${ }^{17}$ seems significant in itself. Surely the period of gestation for ideas cannot be so long, albeit the evidence seems to indicate that it was almost ten years in this situation. For if Congress and its advisers, including Professor Frankfurter, had wanted and had intended to legalize the specified conduct for all purposes in I932, surely it would have taken the trouble to say so. Certainly we may conclude that Congress and its advisers, including Professor Frankfurter, could have had no illusions about how the then-incumbent Supreme Court would interpret the NorrisLaGuardia Act on this point without express words to impel them.

Furthermore, the inclusion of Section 5 in the Norris-LaGuardia Act seems to establish beyond doubt the true meaning of Congress in that statute. In that section, Congress declared: "No court of the United States shall have jurisdiction to issue a restraining order or injunction upon the ground that any of the persons participating and interested in a labor dispute constitute or are engaged in an unlawful combination or conspiracy because of doing in concert the acts enumerated in Section 4

Is Frankfurter and Greene, op. cit. supra note 9, at $226 \mathrm{n}$. $6 \mathrm{r}$.

${ }^{16} \S \mathrm{I} 3$ of the Norris-LaGuardia Act, 47 Stat. 73 (I932), 29 U.S.C.A. § II3 (Supp. I940).

${ }_{77}$ The clause referred to is at the very beginning of $\S 103.53$ of the Wisconsin Statutes (1937), which is to be compared with $\S 4$ of the Norris-LaGuardia Act, and is as follows: "The following acts, whether performed singly or in concert, shall be legal: ...." The Wisconsin act was approved on June 27 , I93I. Wis. I. (I93I) c. 376 . The federal act was approved on March 23, I932. 
of this act." ${ }^{88}$ This is what Congress included directly after Section 4 . Now the language of this Section 5 is strangely suggestive of the language in Section I of the Sherman Act: "Every contract, combination in the form of a trust or otherwise, or conspiracy, in restraint of trade or commerce among the several states, . . . is hereby declared to be illegal."."rg Section 5 of the Norris-LaGuardia Act indicates that Congress had carefully stipulated, out of abundant caution in view of some of the past feats of Court construction, that the act also applies to the injunction sanction of the Sherman Act, whether at the instance of the Attorney General or, in accordance with Section 16 of the Clayton Act, at the instance of private persons. If Congress had intended to resurrect Section 20 of the Clayton Act, and to revitalize the concluding clause of that section in order to make all of the specified conduct lawful for all purposes and not to be "violations of any law of the United States" (including the Sherman Act), it would not have worded Section 5 as it did, but would have said so in so many words, just as it had done in Section 20 of the Clayton Act.

Congress clearly evinced in I932 an intention to prevent the use only of restraining orders and injunctions against labor unionists, even if the illegality of their conduct was pressed under some theory of conspiracy, including that appearing in the Sherman Act. I would expect Mr. Justice Frankfurter to agree, therefore, that any implication in the NorrisLaGuardia Act would seem to be that if the Supreme Court immediately after the act was approved had wanted to overrule the Duplex case and to enforce Section 20 of the Clayton Act in its entirety as he now thinks it should be applied, considered reflection would have kept it from doing so because of Congress' apparent intent to displace Section 20 with the new statute and to relegate the former entirely to history.

Mr. Justice Frankfurter quoted the report of the House Committee on the Judiciary dealing with the proposed Norris-LaGuardia bill, as follows: "The purpose of the bill is to protect the rights of labor in the same manner the Congress intended when it enacted the Clayton Act, .... which act, by reason of its construction and application by the Federal courts, is ineffectual to accomplish the Congressional intent." ${ }^{20}$ Let us assume that this statement is true; still, it does not mean a great deal. Members of the House of Representatives in I932 did not know any more about what Congress intended to enact in I9I4, eighteen years earlier, than we know. Even discounting the suspicion that Congress itself was

${ }^{x 8} 47$ Stat. $7 x$ (1932), 29 U.S.C.A. \& ro5 (Supp. x940).

19 26 Stat. 209 (I890), I5 U.S.C.A. \& I (I927).

206 I S. Ct. 463,468 (I94I). 
merely throwing a sop to the unions in the Clayton Act and was deliberately appearing to say more than it meant, paragraph 2 of Section $20^{2 x}$ was so punctuated with the qualifying words "peaceful," "peacefully," "lawful" and "lawfully," words which should fairly be read in light of the meaning then generally given them in the context in question if the true intent of Congress is sought, that the intent may well have been to leave things as they already were while seeming to do otherwise. At least it is not obvious that Congress meant to do what is generously attributed to it by latter-day Supreme Court justices and by politicians; and there is some respectable support for the interpretation placed on the legislative intent by the Supreme Court in the Duplex case. In any event, as far as the meaning of Section 20 was concerned, we can assume that Congress in I932 had accepted the Supreme Court's interpretation as controlling.

Mr. Justice Frankfurter might well have quoted a House committee report of earlier days and have supported his argument by retailing Congressman Webb's illuminating explanation of the concluding catch-all clause in Section 20 legalizing generally the specified conduct: " $[\mathrm{H}]$ aving recognized and legalized the acts set forth in Section I8 [eventually Section 2o], so far as the conscience side of the court is concerned, the committee feels that no harm can come from making those acts legal on the law side of the court, for anything that is permitted to be done in conscience ought not to be made a crime or forbidden in law."2z It is true that Congressman Webb was ingenuous in supposing that Section 20, up to but not including the catch-all clause, "legalized" and "permitted" the conduct specified merely because Congress had made it non-enjoinable. For this part of the section was not devised to permit anything "to be done in conscience," but was designed rather to prevent misuse of the equitable remedy of injunction and to compel recourse to something more nearly approaching due process and fair play in the trial of labor unionists.

2x "And no such restraining order or injunction shall prohibit any person or persons, whether singly or in concert, from terminating any relation of employment, or from ceasing to perform work or labor, or from recommending, advising, or persuading others by peaceful means to do so; or from attending at any place where any such person or persons may lawfully be, for the purpose of peacefully obtaining or communicating information, or from peacefully persuading any person to work or to abstain from working; or from ceasing to patronize or to employ any party to such dispute, or from recommending, advising, or persuading others by peacef $ı$ il and lawful means so to do; or from paying or giving to, or withholding from, any person engaged in such dispute, any strike benefits or other moneys or things of value; or from peaceably assembling in a lazof $u l$ manner, and for lawful purposes; or from doing any act or thing which might lavefully be done in the absence of such dispute by any party thereto; nor shall any of the acts specified in this paragraph be considered to be violations of any law of the United States." 38 Stat. 738 (rgr 4 ), 29 U.S.C.A. $\$ 52$ ( 1927 ) (italics added).

22 Frankfurter and Greene, op. cit. supra note 9, at I60 n. 108. 
If the committee's, and Congress', inclusion of the catch-all clause depended upon this reasoning, it is small wonder that Congress refused to repeat this anomoly in Section 4 of its 1932 statute. Perhaps Congress in rgr4 complacently accepted the committee's amendment sponsored by Mr. Webb because it felt that in view of the qualifying words "peaceful" and "lawful," taken at their accepted value in their Igr4 context of labor dispute cases, including the Sherman Act, the catch-all clause meant nothing much at all and might be left in as political good will. For this would not be the first time that Congress had passed a law in terms which, because of well-known judicial conventions, it knew amounted to an invitation to the courts to render the statute's innate sterility apparent. This interpretation of the facts, although it may well be decried as mutilating narrowness, seems plain common sense.

The naïveté of Congressman Webb seems pardonable; for even if he was a lawyer by training, he was essentially a politician and a statesman. But this extenuating plea cannot be made by Mr. Justice Frankfurter, since he is essentially a scholar. Hence his statement in the Hutcheson opinion that "that which on the equity side of the court is allowable conduct"23 seems doubly surprising. He apparently assumes that because the remedy of injunction is withdrawn, purely because of the abuses to which it had been put when enforcement of the law was entrusted solely and informally to individual judges, the conduct thought to have been sufficiently unlawful to merit enjoinability had henceforth become perfectly lawful. His reference to the "equity side of the court" heightens the unrealism which colors his remarks. A more realistic picture reveals one human being-a federal district judge- who has various sanctions at his disposal to employ against allegedly over-exuberant labor unionists; and he uses that sanction which the moving party has invoked, be it equitable, civil action for damages, or criminal, common law or statutory. Now the anti-injunction act of 1932 did not make any conduct "allowable" in any sense of the word whatsoever. It merely signified that the judge in question was henceforth forbidden to use the sanction ordinarily employed by the chancellor of the past--the injunction. To build upon this and to call the conduct thenceforth "allowable" is clearly wrong. Nor is it any condonation that the practical effect of rendering certain labor union activity non-enjoinable has discouraged employers and businessmen from pursuing the remaining more formal legal sanctions still available against the conduct of labor unionists thought to be objectionable. If the upshot of anti-injunction legislation has been a virtually complete victory for the unions, that is no more than they were tactically angling for and

${ }^{23}$ See the quotation on pages $504-5$. 
should be no more than they are entitled to. And if aggrieved persons wish to press the more formal legal remedies against them, the fact that they have been deprived of the remedy of injunction is certainly a poor reason for denying them any recourse to the courts in the absence of legislation changing the substantive law.

II

This is the case against Mr. Justice Frankfurter's opinion in United States v. Hutcheson. The antidote, if an opportunity ever occurs for its administration, is for a majority of the Court to treat his entire opinion as dictum and to adopt as the proper rationale of the decision Mr. Justice Stone's opinion. For however the profession may regard the result of the case, they must admit that it was to have been expected after the $A$ pex case. And the position adopted by the Court as a whole toward the Sherman Act as it bears on labor union activities is thoroughly defensible, once it has taken the jump required in holding that unionization of entire industries is acceptable as a means of keeping non-union goods from competing in national markets with union-made goods-a jump which the Court took in the Apex case with colors flying. ${ }^{24}$

What the profession must find hard to take is not the result but the frank avowal in the majority opinion of Mr. Justice Frankfurter that the Court is willing to strain the words of Congress-to read legislation in a spirit of mutilating broadness-just as long as it may achieve the result it thinks desirable. This technique is one which the liberals deplored when it was exercised by the members of the old Court. It may be said for some of the former incumbents, however, that they probably never doubted what they said. But this is hard to believe of anybody with Mr. Justice Frankfurter's well-known perspicuity. Still, it is an amazing psychological phenomenon how far a wish can carry one. Nor does the quotation from Holmes help Mr. Justice Frankfurter's argument.. ${ }^{25}$ Holmes in his

${ }_{24}$ Cf. Stone, J., in Apex Hosiery Co. v. Leader, 310 U.S. 469, 503-4 (I940). See also Gregory, Labor's Coercive Activities under the Sherman Act-The Apex Case, 7 Univ. Chi. L. Rev. 347, 352 (r940), and Gregory, The Sherman Act v. Labor, 8 Univ. Chi. L. Rev. 222, $24 \mathrm{I}-43$ (I94I).

${ }^{25} 6$ I S. Ct. 463,468 (I94I), quoting Johnson v. United States, 163 Fed. 30,32 (C.C.A. Ist x908): "A statute may indicate or require as its justification a change in the policy of the law, although it expresses that change only in the specific cases most likely to occur to the mind. The Legislature has the power to decide what the policy of the law shall be, and if it has intimated its will, however indirectly, that will should be recognized and obeyed. The major premise of the conclusion expressed in a statute, the change of policy that induces the enactment, may not be set out in terms, but it is not an adequate discharge of duty for courts to say: We see what you are driving at, but you have not said it, and therefore we shall go on as before." 
greatness has become something like Scripture-he can frequently be quoted on both sides of an argument; and the quotation which Mr. Justice Frankfurter includes in his opinion neatly proves my point.

Mr. Justice Roberts, in his brief but pointed stricture on the interpretative process employed by Mr. Justice Frankfurter, cloaks beneath his judicial dignity a resentment which $I$ have been less able to conceal. ${ }^{26}$ Indeed, a remark of Professor Frankfurter's in The Labor Injunction suggests an adequate commentary on the technique he employed in the Hutcheson case. Concerning the judicial working over which Section 20 of the Clayton Act had received at the hands of the Supreme Court, he wrote: "The result justifies an application of a familiar bit of French cynicism: the more things are legislatively changed, the more they remain the same judicially." ${ }_{27}$ In view of the sentiments approved by a majority of the present Court, I am inclined to believe that the less things are legislatively changed, the less they remain the same judicially.

Before concluding, I want to remark that I have written this because I don't want to see Mr. Justice Frankfurter establish his bizarre interpretation of the Congressional acts involved, particularly that part of it portraying the net effect of the Norris-LaGuardia Act. I feel particularly concerned because he tries to clinch his position by pointing out that a contrary interpretation would be ignoring the will of Congress by construing the intent "in a spirit of mutilating narrowness." he has presented an entirely false picture of what Congress undertook to do in passing the Norris-LaGuardia Act. If social changes are to take place rapidly in our country, I believe that our legislatures should introduce them. They alone are answerable directly to the political pressures registered at the polls on election day. ${ }^{29}$ If there is any "mandate of 1936 " 30

${ }^{26}$ In his dissent Justice Roberts said: "By a process of construction never, as I think, heretofore indulged by this court, it is now found that, because Congress forbade the issuing of injunctions to restrain certain conduct, it intended to repeal the provisions of the Sherman Act authorizing actions at law, and criminal prosecutions for the commission of torts and crimes defined by the anti-trust laws. The doctrine now announced seems to be that an indication of a change of policy in an Act as respects one specific item in a general field of the law, covered by an earlier Act, justifies this court in spelling out an implied repeal of the whole of the earlier statute as applied to conduct of the sort here involved. I venture to say that no court has ever undertaken so radically to legislate where Congress has refused to do so." 6r S. Ct. 463, 472 (194I).

27 Frankfurter and Greene, op. cit. supra note 9, at 176 .

${ }^{28}$ See the quotation on pages $504-5$.

29 This plea for allowing legislatures to establish controlling economic and social policy is essentially what I was driving at in Gregory, Peaceful Picketing and Freedom of Speech, 26 A.B.A.J. 709 (1940).

${ }^{3 \circ} \mathrm{Cf}$. the remarks of Gadola, Circuit Judge, in General Motors Corp. v. TUAWA (Genesee County, Michigan 1937), reprinted in Landis, Cases on Labor Law I9 (1937 Supp.), in grant- 
or of I940, it is not for the courts to react to it as men of good will. Policy-making in a democracy is the function of the legislatures. The courts certainly share this function to the extent that they ultimately declare what these social values are in particular cases. But this function does not privilege them to write anew where Congress has already spoken. The present court had already declared what the Sherman Act means in its application to labor unions before the Hutcheson decision came down. ${ }^{3 x}$ Mr. Justice Stone completed the job, as far as he was concerned, within the purview of his designated task. It now remains to be seen whether Congress will let Mr. Justice Frankfurter's "extrapolation" stand.

Congress may have to deal firmly with the current over-exuberance of labor unionists in wasteful jurisdictional disputes, both between crafts of the same federation and between federations themselves, and in the defiance of certifications by the National Labor Relations Board. No doubt Congress intended in the National Labor Relations Act to obviate labor strife by giving labor the organizational facilities for which they had been struggling over a century. But the upshot has been an entirely unforeseen exploitation of Section $I 3$ of that act; $;^{32}$ and the area of disputes has been broadened and their intensity heightened since its passage. Many fear that Congress may react too violently against this new exuberance and may introduce checks of such a severe nature under the name of imposing correlative responsibility on the unions as to imperil much of the social gain achieved during the past few years. Hence it behooves us not to push too fast or too far and to leave social development to the body best equipped to direct it.

What area remains within which the Sherman Act still applies against labor? In general, it might be said still to apply where a union cooperates with one or more manufacturers to police a competitive area in an attempt to exclude the commodities of non-members of the combination. This, I take it, is approximately the Brims case. But suppose that the union exercises its power against the introduction of certain commodities, without combining with producers, because it dislikes the economic effect of such commodities on immediate union welfare? The "concrete mixer"

ing an injunction in a sit-down strike: "At the outset of the argument on behalf of the defendants, counsel stated that we were now not operating under the laws of 1898 , but were operating under the clear mandate of the people as expressed in 1936, probably referring to the election of $1936 . "$

${ }^{3 x}$ Apex Hosiery Co. v. Leader, 3I0 U.S. 469 (1940).

32 "Nothing in this Act shall be construed so as to infertere with or impede or diminish in any way the right to strike." 49 Stat. 457 (I935), 29 U.S.C.A. § I63 (Supp. I94O). 
case $^{33}$ is a good example of what $I$ have in mind. A union which feared that ready-mixed concrete trucks will deplete the demand for its members in the building trades refused to allow its members to work on them unless unnecessary men were hired to "assist" in operating them. As a consequence, the trucks were not bought and thus the "interstate commerce" in them is destroyed - that is, out-of-state markets for them are suppressed. While this might seem to be a violation of the Sherman Act within Mr. Justice Stone's position, can it not be said that this stoppage of importation is no "more than that which is incidental to every strike causing a shutdown of a manufacturing plant whose product moves in interstate commerce or stopping building operations where the builder is using material shipped to him in interstate commerce," ${ }^{34}$ to use his own words from his Hutcheson opinion? And cannot the same be said of the new "kitchen cabinet" case? ${ }^{35}$ Likewise, the "plywood" case ${ }^{36}$ seems to fall within this test.

And what about the Brims case itself-that case which we all assume would stand up even today if it were again to arise before the Court? ${ }^{37}$ I think we had better reconsider this assumption, for the Court has committed itself so far that even Mr. Justice Stone might find it difficult to retract sufficiently to maintain a conviction in that case. After all, it is not signally different from the situation which appeared in the Lake Valley case. ${ }^{38}$ The Court merely decided in that case that there was a "labor dispute" and that no injunction might issue. Nevertheless, since "the union acts in its self-interest," to quote Mr. Frankfurter, "and does not combine with non-labor groups," ${ }_{39}$ except to maintain a trade agreement with unionized distributors, where is the offense against the Sherman Act by unionists who articulate their embargo on "outside" milk by picketing -conduct fairly described in Section 20 of the Clayton Act and in Section 4 of the Norris-LaGuardia Act? I take it that if the Brims case were

33 United States v. Carrozzo, an indictment returned in the United States District Court for the Northern District, Eastern Division, of Mllinois on June 24, I940. The Government lost this case.

${ }^{34} 6$ I S. Ct. 463,470 (194I).

35 United States v. Goedde \& Co., an indictment returned in the United States District Court for the Eastern District of Tllinois, September 2r, $194^{\circ}$.

${ }^{36}$ United States v. United Brotherhood of Carpenters and Joiners of America, an indictment returned in the United States District Court for the Northern District, Eastern Division, of Illinois, on February I, 1940. The Government lost this case.

${ }^{37}$ See assurances of this in the opinion of Stone, J., in Apex Hosiery Co. v. Leader, 3 Io U.S. 469 , 5or ( 1940 ), and the dictum of Frankfurter, J., referred to in note 5 supra.

${ }^{8}$ Milk Wagon Drivers' Union v. Lake Valley Farm Products, Inc., 6r S. Ct. I22 (1940).

396 I S. Ct. 463,466 (I94I). 
to arise again, the sole inquiry of at least four members of the present Court would be: How did the union exert its exclusionary pressure? If it was by picketing, by strilke or by boycott or by any conduct which might fairly be said to have been described in either of the sections justreferred to, then according to Mr. Justice Frankfurter there would be no violation of the Sherman Act no matter how drastically the union sanction would have imposed a control on a commodity market. For would not the union have been acting in self-interest in keeping out "non-union" goods, even if they were union-made but fabricated by a competing union?

Are not the Lake Valley and the new "kitchen cabinet" cases very much like the Brims, case in this and in other respects, including the feature of combination with non-labor groups? It looks as if the only escape, lacking a clear pronouncement from Congress to the contrary, is for those interested in the unrestricted movement of goods in national markets to "play ball" with the unions-and with the right unions, at that. Whether or not this pessimistic forecast is to be the last word, without further legislation, may be revealed in the near future, for the Anti-trust Division of the Department of Justice is said to have been allowed to appeal directly to the Supreme Court in the "plywood" and the "concrete mixer" cases. But even this locus poenitentiae will not afford an opportunity to instruct the profession concerning the Court's attitude toward violations of the Sherman Act as flagrant as that in the old Brims case.

\section{AND WHAT OF THE APEX CASE NOW?}

David F. Cavers*

TN the February number of the Review Mr. Gregory and I set forth in separate articles our respective views concerning the applicability of the Sherman Act to labor restraints, in the light of the Apex case. ${ }^{\mathrm{x}}$ $\mathrm{Mr}$. Gregory, in the preceding comment, now returns to the problem with his analysis of the majority's position in the recent Hutcheson case. My present comment, discussing chiefly the relation of that case to its predecessor, the Apex case, is not self-suffcient; for its full understanding, a reading of my previous article and Mr. Gregory's comment on the Hutche-

* Visiting Professor of Law, University of Chicago (1940-4I); Professor of Law, Duke University; Editor-in-Chief, Law and Contemporary Problems.

I Gregory, The Sherman Act o. Labor, 8 Univ. Chi. L. Rev. 222 (I94I); Cavers, Labor v. The Sherman Act, 8 Univ. Chi. L. Rev. 246 (I94I). 